\title{
Is R2P Still Controversial? Continuity and Change in the Debate on 'Humanitarian Intervention'
}

\author{
Noele Crossley* \\ University of Oxford \\ noele.crossley@qeh.ox.ac.uk
}

\begin{abstract}
Is the responsibility to protect $(R 2 P)$ still controversial? The question is important because if $R 2 P$ was no longer controversial, this would suggest that the principle is on track to consolidation as an international norm. The article assesses the impact of sixteen years of sustained $R 2 P$ advocacy and its influence on arguments within the scholarly community, and discusses the impact this engagement has had on the outline and substance of the principle itself. A survey of the development of the academic debate since 2005 suggests that the 'responsibility to protect' has successfully replaced 'humanitarian intervention' in the international discourse, but that the principle remains controversial, especially beyond the policy community, particularly in the world of academe, with the humanitarian aid sector and religious organisations, as well as with states with a colonial past.
\end{abstract}

Keywords: the responsibility to protect; humanitarian intervention; norm entrepreneurship; norm advocacy; norm consolidation

Acknowledgements: The author would like to thank Chris Brown, Ramesh Thakur, as well as three anonymous reviewers for helpful comments on earlier drafts of this article. The author retains sole responsibility for the argument and any errors or omissions.

* Noele Crossley is a Departmental Lecturer in Global Governance in the Department of International Development at the University of Oxford. She was awarded her $\mathrm{PhD}$ from the London School of Economics and Political Science. Her research interests are in the areas of security studies and peace and conflict studies, revolving in particular around atrocity prevention and the responsibility to protect. She is the author of 'Evaluating the Responsibility to Protect' (Routledge 2016).

Advocates contend that sixteen years of responsibility to protect (R2P) advocacy have resulted in the widespread acceptance of a principle considered highly controversial when it was first tabled. In 2006, five years after the publication of the report that coined the responsibility to protect (ICISS 2001), Thomas Weiss suggested that if one was to plot 'the growing consensus about R2P on a graph', it would 'reflect a steady growth' (Weiss 2006). By 2011, Gareth Evans argued that there was an 'overwhelming consensus, at least on basic principles', and proclaimed the 'end of the argument' in a Foreign Policy article (Evans 2011). In the same year, Monica Serrano dismissed the critics' contention that R2P was a 
North-South polarising issue and therefore controversial as a 'deliberate misrepresentation in a rhetorical war' (Serrano 2011).

However, a significant number of scholars, policy-makers, and practitioners continue to express grave reservations about $\mathrm{R} 2 \mathrm{P}$, and remain sceptical or even hostile towards the principle. A range of arguments have been levelled at $\mathrm{R} 2 \mathrm{P}$ over the last decade or so. While some of the critique has quietened, and the kinds of arguments that are being articulated in opposition to R2P have changed, some elements of the critique continue to persist. Undoubtedly the principle has had a profound influence on international discourse, successfully replacing 'humanitarian intervention' ${ }^{1}$ as the dominant frame of reference; it is no longer possible to discuss atrocity prevention and intervention on humanitarian grounds without reference to the principle or without using terminology associated with the ' $R 2 P$ jargon'. But despite these monumental changes, the claim that the debate is now over is a big one and therefore worth investigating. Have the changes we observe in the international discourse been significant enough to suggest that there is now - as proponents suggest $-\mathrm{a}$ genuine consensus on $\mathrm{R} 2 \mathrm{P}$ ?

This question is important because the idea of a 'consensus' implies that the debate has been settled, and, implicitly, suggests that the responsibility to protect may be on track to becoming a norm of international society; shaping perceptions of appropriate responses to crises that give rise to large-scale systematic violations of human rights, and ultimately, compelling states to react in response to such crimes. However, the responsibility to protect is a complex principle in that it both prescribes as well as proscribes certain forms of behaviours (Welsh 2013, 384). Hence, the responsibility to protect can be said to entail both a license (permissive), as well as a leash (restrictive) function - which exposes the principle to potential criticism from two opposite sides; those who suggest that R2P may be 'too much', versus those who suggest R2P may be 'too little' (Weiss 2004). Consequently, if R2P became a settled norm of international society it would compel states to act in certain ways, and not others. $^{2}$

In order to establish whether the debate within the scholarly community reflects a broader trajectory towards norm consolidation, this article traces the development of the debate on intervention and responses to egregious and systematic human rights violations over the course of the last two decades, which coincides with a period of sustained R2P advocacy beginning in 2001. The article describes the exchange of arguments between R2P proponents and critics, assessing whether R2P advocates have 'won' any of the arguments in this socalled 'rhetorical war' (Serrano 2011); and whether, more generally, they have been

\footnotetext{
${ }^{1}$ The International Commission on Intervention and State Sovereignty (ICISS) developed the 'responsibility to protect' as an alternative to 'humanitarian intervention', in response to the political fallout following NATO's intervention in Kosovo in 1999. For an authoritative account of the differences between the two concepts, see Thakur (2017).

${ }^{2}$ The social constructivist literature on norms, their emergence, and theories about their influence on perceptions of appropriateness as well as discourse and behaviour is substantial. The following texts provide a useful overview and critical discussion of constructivism as a methodological approach: Adler (1997); Hopf (1998). The classic text suggesting the model of the 'norm life cycle', to which reference is made frequently here, is Finnemore and Sikkink (1998).
} 
successful at persuading a wider audience within the larger epistemic community in the field of human rights protection and the responsibility to protect. $^{3}$

The epistemic community around the responsibility to protect is comprised of three distinct, yet interrelated spheres: the academic community of scholars working on intervention and mass atrocity prevention; policy-makers in governments and international organisations; as well as members of think tanks, humanitarian relief organisations, and the media. Within this epistemic community - as in any other epistemic community, of which examples will be provided further on - academic and policy debates serve as normative battlegrounds in which contestants seek acceptance of their ideas. Norm advocates promote new norms through academic debate and advocacy, either explicitly, through academic and media publications, as well as through deliberations at international organisations; or implicitly, referring to certain principles, or couching their arguments in a particular language (Finnemore and Sikkink 1998; Keck and Sikkink 1998; Keck and Sikkink 2002). Thus, advocates for the responsibility to protect have been promoting the principles - as well as the ideas associated with it - both explicitly, through publications in academic journals and the broader media, as well as implicitly though their research agendas and programmes, as well through the adoption of a particular kind of language that communicates endorsement of, and agreement with, the key principles associated with R2P.

While this article is focused on the scholarly debate, it is assumed here that there is a dynamic relationship between debates playing out within this community and the broader epistemic community as well as a broader audience of non-expert policy-makers, governmental practitioners, and the international public. Given the influence of these networks in a wide range of issue areas, it can be assumed that the epistemic community on $\mathrm{R} 2 \mathrm{P}$ could - at least in theory - have a similar kind of impact. Keck and Sikkink's description of transnational advocacy networks $(1998 ; 1999)$ is instructive here. Keck and Sikkink suggest that networks of actors - in this case networks of experts and activists in the humanitarian domain - can act as 'key contributors to a convergence of social and cultural norms' $(1999,89)$. Consequently, the aim here is twofold: to establish whether similar dynamics are at play with regard to the advancement of the R2P principle, that is, to what extent, and how international actors have been interacting to advance a particular set of social norms (the principles associated with the responsibility to protect); and, second, to establish to what extent these efforts have been successful and whether, as a consequence, we can now indeed speak of a genuine 'consensus', as R2P advocates suggest. If such a consensus were to exist, it would suggest that the responsibility to protect has consolidated as a norm that is likely to play a significant role in shaping international practice.

\footnotetext{
${ }^{3}$ An 'epistemic community' consists of experts and their wider networks and communities. They 'play an increasingly important role in communicating knowledge, in defining international problems, and in shaping policies' (Meyer 2015). Epistemic communities exist in all areas of international policy-making, including, for example, health, the environment, or the economy. Historically, such epistemic communities have been influential in bringing about change in a range of issues areas. Examples include the influence of the international environmental epistemic community in bringing about a ban on chlorofluorocarbons (Haas 1992), the role of the Delors Committee in the creation of the EMU (Verdun 1999), the role of epistemic communities working in the field of HIV/AIDS (Youde 2005), in the field of health in combating the global consumption of tobacco (Mamudu 2011), or the work of epistemic communities in promoting the recognition of climate change as a man-made (anthropogenic) risk that has to be managed (Gough and Shackley 2001).
} 
In order to do so, this article engages with the development of the discourse on R2P, both in the realm of international political theory, as well as the implications in terms of policy; specifically, the international debate on criteria for intervention (which resurged at the end of the 1990s in the context of the Kosovo intervention and Tony Blair's 'doctrine of the international community', and continued to occupy key thinkers into the early 2000 s and through the early years of R2P's conceptualisation). While a substantial body of literature discusses norm advocacy for R2P (Thakur and Weiss 2009; Knight 2011; Acharya 2013), and, within the field of international political theory, there has been some discussion of critical perspectives on R2P (Cunliffe 2011) there has been little to no engagement with the more theoretical scholarly debates and their impact on policy, as well as what, in turn, a potentially shifting discourse within this realm may tell us about the status of R2P as a norm.

It may be worth briefly outlining the key goals of R2P advocacy. At its core, R2P norm advocacy seeks to eventually reconfigure international priorities, elevating the protection of populations from atrocity crimes over state sovereignty and the associated principle of nonintervention. Needless to say, despite the principle's narrow focus, the implications for international order are profound. Advocacy for the responsibility to protect has not been operating in a normative vacuum, but challenges the traditional conception of state sovereignty, territorial integrity, and non-interference. Unsurprisingly, therefore, it has been met with obstinate rejection from a variety of critics for whom state sovereignty and nonintervention constitute the normative bedrock of international society. Has the academic debate between advocates for R2P and its critics had broader effects on the advancement of the norms associated with the principle beyond the immediate epistemic community? Do they serve as a vehicle of normative change (Risse 2000)? What, in turn, has this meant for R2P as a consolidating norm of international society? If $\mathrm{R} 2 \mathrm{P}$ advocates have indeed been successful at restructuring the international discourse and perceptions of appropriate responses during crises in which atrocities are ongoing or imminent, what was the process by which this consensus was reached? Which strategies did R2P norm advocates adopt to increase support for the principle? Did R2P change conceptually as a result, and if so, in what ways?

I begin with a brief outline of the origins of R2P norm entrepreneurship beginning in 2001, and the ideological perspective from which R2P developed. This is followed by a discussion of the critical perspectives on R2P that emerged in response to the ICISS report and the subsequent advocacy for the responsibility to protect. I suggest a typology of the main critical arguments - postcolonial, feminist, pacifist, and pluralist - and then outline a dynamic process of argumentation, which has also resulted in the conceptual refinement of the principle. ${ }^{4}$ The article concludes with a discussion of the extent to which R2P advocacy has indeed resulted in a 'consensus' within the academic community and beyond, and the implications in terms of R2P's consolidation as an international norm.

\footnotetext{
${ }^{4}$ There are other critical arguments but these do not fit neatly into the categories outlined here. See Kuperman (2008) on 'moral hazard'; Brown (2013), on R2P as antipolitical theory; or Paris (2014) on 'structural' problems inherent in R2P as a concept. The latter argues that limited, surgical military responses aimed at realising a narrow set of objectives (the prevention of atrocities) are not in most cases feasible without removal of the regime of the target state, which are typically at least partially responsible for the atrocity crimes. See also Thakur's response to Paris (2015).
} 


\section{The Emergence of the Responsibility to Protect}

Advocates of the R2P sought, over the past decade or so, to advance a discourse that prioritises specific human rights concerns over other established norms, particularly state sovereignty and territorial integrity. The 'responsibility to protect' was first articulated in a 2001 report by the International Commission on Intervention and Statebuilding (ICISS 2001). The concept as articulated in the report emphasised the importance of 'prevention' and 'rebuilding'. 'Reaction' - comprising both non-coercive and non-military coercive measures (diplomacy and sanctions, respectively) - became sandwiched between 'prevention' and 'rebuilding'. By embedding reaction within a comprehensive framework including prevention and reconstruction (Bose and Thakur 2016), the architects of the report attempted to build on, transform, and transcend the hitherto prevailing concept of 'humanitarian intervention'. 'Humanitarian intervention', R2P proponents argued, focused on military intervention and the rights and duties of the intervening party, and needed to be reoriented towards facilitating the protection of populations at risk.

The impetus for the ICISS report came from the intense debates over international responses to a string of humanitarian crises in the wake of the Cold War, particularly the Rwandan genocide and the crisis in Kosovo (Thakur 2016a). However, the 'responsibility to protect' as an idea is the product of diverse antecedents going back to the Cold War era (Dunne and Staunton 2016). The most important building blocks included the emerging practice of the provision of humanitarian relief irrespective of government consent (Allen and Styan 2000); the developing doctrine of UN peacekeeping (Boutros-Ghali 1992); the idea of 'sovereignty as responsibility', coined by Francis Deng, in relation to the protection of internally displaced people (IDPs) (Deng 1995); and former UN Secretary-General Kofi Annan's endorsement of the idea of 'sovereignty as responsibility' in 1999 (Annan 1999; Annan and Mousavizadeh 2012). '[S]overeignty as responsibility' (Deng 1995) proposed that state sovereignty and the responsibility to protect people from large-scale human rights violations and mass atrocity are co-constitutive, that is, that a state that fails to protect its citizens is no longer a legitimate sovereign state. This idea formed the basis for the subsequent articulation of the responsibility to protect in 2001 (Bellamy 2009).

As a result of intense campaigning for the principle, states endorsed R2P at the World Summit in 2005 (United Nations 2005). Although the reference to R2P was severely truncated when compared to the ICISS report, the endorsement did reflect a lowest common denominator $-\mathrm{a}$ 'consensus' in its crudest form. States agreed on a responsibility to protect from genocide, ethnic cleansing, war crimes, and crimes against humanity: if a state was 'manifestly failing' to meet this responsibility, the responsibility would fall to the international community (ibid). Still, the R2P paragraphs were vague and, rather than indicating a clear path forward in terms of implementation, appeared to raise fresh questions and spark new controversy. Supporters viewed the endorsement of R2P as a success; sceptics pointed to the ambiguity in the way R2P had been articulated and argued that the World Summit paragraphs had implicitly rejected the more far-reaching ICISS version of the responsibility to protect.

Several years later the Special Adviser for the Responsibility to Protect, then Edward Luck, outlined a three pillars approach for implementing R2P in a 2009 report of the SecretaryGeneral (United Nations 2009). The 'three pillars approach' emphasised government cooperation and consent, suggesting that only if a situation is such that a state was manifestly failing to protect its population and outside support was ineffective or denied, the responsibility falls to the international community. Pillar one stood for 'the protection 
responsibilities of the state', pillar two for 'international assistance and capacity-building', and pillar three for 'timely and decisive response' from the international community. The report had a profound impact on the conceptual development of R2P, as it identified the use of force as but one of a range of measures at the disposal of states in meeting their collective responsibility to protect when a state fails to meet its primary responsibility to do so.

The conceptual development of R2P played out against a backdrop of debate on R2P's implementation and its applicability in particular cases; dynamics that both affected, and were affected by, the developing discourse in the epistemic community. These interactions are not the focus of this article, but a number of cases stand out in terms of their impact on the debate and are worth briefly mentioning here. These include the crises in Georgia, Myanmar, Libya, and Syria. The attempt to invoke R2P and the rejection of this framing in the case of Georgia provided an opportunity for identifying the conditions under which R2P could reasonably be applied - i.e., an exercise in interpretation (Badescu and Weiss 2010). The attempted invocation of R2P in the case of Myanmar, in which authorities refused to facilitate humanitarian aid in the aftermath of cyclone Nargis, sparked controversy whether $\mathrm{R} 2 \mathrm{P}$ applied to humanitarian crises; with most commentators subsequently arguing that $\mathrm{R} 2 \mathrm{P}$ should not be invoked in response to humanitarian crises unless a state's response to such a crisis resulted in R2P crimes (Haacke 2009, Badescu and Weiss 2010). The intervention in Libya played a central role given that the Security Council resolution providing a mandate for the intervention explicitly referred to $\mathrm{R} 2 \mathrm{P}$. The international response to the crisis and the willingness to invoke R2P in this context appeared to suggest a 'consensus' had formed only for this assessment to be put into jeopardy shortly later with the unfolding crisis in Syria.

\section{Critical Perspectives on the Responsibility to Protect within Academia and Beyond}

The first years of R2P advocacy proved difficult, with R2P supporters seemingly unable to assuage concerns about the potential misuse of the concept. The most outspoken academic critics were Mamdani, Chandler, Chomsky, Hehir, O'Connell, and Cunliffe. These scholars, whose individual arguments are discussed in more detail below, criticised R2P on different grounds, questioning, in theoretical terms, R2P's ability to mediate between competing international norms; R2P's ability to deliver in practice what it promised in theory; or whether it provided a humanitarian pretext for intervention. Postcolonial sceptics regarded R2P as a form of neo-imperialism, suggesting that R2P was merely a 'Trojan Horse' - a doctrine intended to justify overly interventionist policies (Bellamy 2005). But between the extremes at both ends - advocates and hostile critics - there were a range of moderate views that were more ambiguous, so the initial schism between ' $\mathrm{R} 2 \mathrm{P}$ supporters' and 'R2P sceptics' should not be overstated. While supporters and moderate critics tended to focus on issues of conceptual refinement, norm consolidation, and implementation, the real 'critics' were united by their more fundamental scepticism about R2P at a conceptual level. While objections to 'humanitarian intervention' related to the use of force, objections to R2P were much broader, and focused on the concept in its entirety, which included, but was not limited to, military intervention. These various perspectives criticised R2P for different reasons, but what they shared in common was that they regarded R2P as 'too much', rather than 'too little'.

The postcolonial critique 
The postcolonial critique was grounded on the suspicion that R2P could serve to justify (unilateral) military action or foreign interference in domestic affairs, justified with the protection of populations at risk. From this perspective, R2P was an unsavoury attempt to justify - and even replicate - an inherently unequal international system. Similarly, Mahmood Mamdani (2010) argued that R2P was a conscious policy effort aiming to strengthen Western domination of Africa, with the aim of normalising Western governance in the region. Philip Cunliffe argued that weaker states were unlikely to have a say regarding when and how R2P was going to be implemented. Consequently, he argued, R2P's reconceptualization of sovereignty posed a threat to the international system, because ' $[\mathrm{t}]$ aking away the right to non-intervention is like the erosion of civil liberties in domestic politics or revoking the presumption of innocence in criminal law' $(2010,84)$. As a result, Cunliffe argued, weaker states were going to be even less able to control and influence their own affairs. R2P was aiming to transform a right of intervention into a duty that states would be able to enforce at their own discretion, creating potential for abuse. At the same time, he argued, R2P remained an imperfect duty, unable to offer any guarantees of security: 'the "responsibility to protect" could cruelly raise expectations of outside support that have little hope of ever being fulfilled' (86). While the architects of the principle never intended it to shape international law in such a way as to create a new 'duty', the critique that R2P was unable to offer any guarantees of security was acknowledged by the proponents. Intriguingly, in this sense the postcolonial critique is ambiguous - critiquing the principle both on the grounds that it was too much, potentially an impingement on state sovereignty, as well as that it was too little; unable to provide protection where vulnerable populations were at risk.

\section{The pacifist and feminist critiques}

Postcolonial arguments constituted the mainstream source of R2P critique. At the margins, however, another strand of R2P critique objected to the principle on the grounds that it overemphasised, or even promoted, the use of force. One of the most vocal critics of R2P on the grounds that it promoted the use of force in the pursuit of humanitarian ends was Mary Ellen O'Connell. In 2008, in a heated debate with Ramesh Thakur, O'Connell argued that R2P should stand for a 'Responsibility to Peace', but that it actually signalled a new militarism (O'Connell and Thakur 2008). In 2009, O'Connell argued that 'Ending a war and preventing its reoccurrence is the work of peacemakers. $\mathrm{R} 2 \mathrm{P}$ is associated not with peace but with war and should be quietly allowed to fade away' (O'Connell 2009). One year later, she suggested that the emergence of a discourse on a responsibility to protect reflected a 'new militarism' in international relations (O'Connell 2010). Other scholars have made similar arguments, and these sentiments go some way towards explaining the scepticism of others within the epistemic community(most notably humanitarian aid organisations) about R2P; to be discussed in further detail later on.

Feminists constituted another group of sceptics, although feminist engagement with R2P was scarce up until the publication of Hilary Charlesworth's article, 'Feminist Reflections on the Responsibility to Protect in Global Responsibility to Protect in 2010 (Charlesworth 2010; Harris-Rimmer 2015). The feminist critique of R2P encompassed the pacifist critique of war, but also criticised the particular androcentric quality of R2P. Given the historical links between feminism and peace activism (Frazer and Hutchings 2014), it was not surprising a particular kind of feminist-pacifist argument emerged in relation to R2P. Feminist pacifists, or, using a term employed by Sara Ruddick, 'anti-war feminists', are absolute pacifists (ibid), arguing that patriarchy, war, and violence are intrinsically connected; that instrumental justifications of violence should be rejected; and suggesting instead that non-violent ways of 
resisting domination need to be employed. Not all feminists are pacifists, and not all pacifists - 'one who believes that ... war is a kind of violence not justified in any circumstances'

(Teichman 1982, 72) completely disavow any use of force (Childress 2010), but pacifists are more sceptical of the ability of the use of force to yield desired outcomes, and much feminist scholarship draws on pacifist arguments. ${ }^{5}$ Feminists have different perspectives on war, but have in common that they regard war as intricately tied to gender inequalities and gendered violence (Cockburn 2012). Unsurprisingly, therefore, the initial response to R2P by feminist scholars, for the most part, was one of scepticism. Feminists were wary of a doctrine that intended to formalise principles that entailed the use of force as a policy option.

A more specific feminist argument levelled at R2P concerned its androcentric quality, especially in the way it had first been codified in the ICISS report. Bond and Sherret, for example, argued that R2P was 'gender-blind' (Bond and Sherret 2006), failing to address the subordination of women and the way violence shapes women's lives (Charlesworth 2010, 248), and that '[i]ts design has been influenced by men's lives and the dominance of masculine modes of reasoning' (Ibid, 240). The fact that the ICISS Commission included just one woman, Gisèle Côté-Harper, was of symbolic significance. Charlesworth argued that the under-representation of women on the Commission reflected a broader tendency of the report to ignore the central role gender plays, both in bringing about the situations that necessitate humanitarian action, as well as in conflict mitigation and post-conflict peacebuilding.

\section{The pluralist critique}

Another strand of R2P critique originated from the pluralist perspective, which traditionally stands in contrast to solidarist arguments about intervention. ${ }^{6}$ The pluralist argument was unsympathetic to efforts to universalise ethical codes and norms that are regarded as contextually grounded. Furthermore, pluralist thinkers were concerned about the implication that intervention on humanitarian grounds was to become a duty or obligation, rather than remain, as has been customary, a discretionary right. For this reason, pluralists were more comfortable with the idea of 'humanitarian intervention': the idea that the decision to intervene is an exceptional measure in response to exceptional circumstances.

From a pluralist perspective, therefore, R2P was regarded with scepticism because it threatened to destabilise the prevailing normative order. In 2006, shortly after R2P's endorsement at the World Summit, David Chandler argued that international relations have become increasingly hierarchical with 'stratified forms of sovereignty' (Chandler 2006, 245). Chandler argued that ' $[\mathrm{w}]$ hile leading Western states are acquiring special privileges of hegemony, other states are losing the basic rights of sovereignty,' suggesting that R2P could erode state sovereignty by delegitimising sovereign states with weak institutions (246). From the outset, Chandler argued, the concept had merely attempted to promote the acceptability of military humanitarian intervention, and 'prevention' and 'rebuilding' had been included in the ICISS report merely to sell the doctrine (Chandler 2010). Slightly contradictory (but no less critically), Chandler also argued that 'prevention' and 'rebuilding' constituted 'the key

\footnotetext{
${ }^{5}$ The classical feminist argument about violence incorporates these pacifist assumptions and is encapsulated in the work of Cynthia Cockburn (2007).

${ }^{6}$ English School theory is characterised by a debate between solidarists, who suggest states can act in solidarity to enforce international law, and pluralists, who argue that states act in solidarity only when it is in their interest to do so. See Bull (1966).
} 
normative justification for the more indirect forms of intervention associated with international statebuilding' (164).

Another sceptical voice exemplifying the critics in this category was Robert Pape (2011). In an article in 2011, Pape vigorously criticised the responsibility to protect, on the grounds that the principle, if realised, requires intervention in a much larger number of cases, in this way corroding the norm of state sovereignty and undermining the present normative international order. While 'humanitarian intervention' set the bar for intervention much higher, requiring states to prove that genocide was occurring before they could legitimately intervene, R2P, he argued, set the bar much lower: 'R2P sets the bar for intervention so low that virtually every instance of anarchy and tyranny - or indeed, every potential instance - represents an opportunity for the international community to violate the sovereignty of states' (Pape 2012, 43). This view represented the position of numerous other thinkers who were sceptical of $\mathrm{R} 2 \mathrm{P}$ on the grounds that it threatened to undermine, confuse, and potentially destabilise, the existing normative framework structuring the international relations of states.

\section{Engaging with the Critical Perspectives, Refining R2P}

The publication of the ICISS report marked the beginning of an intensive debate on the meaning of $\mathrm{R} 2 \mathrm{P}$ on the one hand, and on its value on the other. R2P advocates defended the newly conceptualised principle, and sought to expand its influence, which entailed engaging with the emerging critical perspectives on R2P. This continuous process of engagement left its mark on the principle in conceptual terms: the principle gradually became more expansive, advocating a tailor-made approach to humanitarian crises, rather than set of one-size-fits-all list of threshold criteria and principles. Furthermore, R2P advocates emphasised the preventative dimension of R2P; highlighted the role of regional organisations; aligned R2P with the Women, Peace, and Security (WPS) agenda; and stressed the sovereign state's position as at the centre of the principle and with a primary responsibility to protect people within its borders. All of these measures were taken in an effort to provide reassurance that R2P was not 'too much' (merely providing a licence for intervention); but that it could work to provide a framework for targeted responses to mass atrocities (a licence, but also a leash; a framework that comprised both a permissive as a well as a restrictive function). The following section outlines R2P advocates' responses to the critical arguments in more detail, demonstrating how these, in turn, led to the conceptual refinement of the principle.

In response to the postcolonial critique that viewed $\mathrm{R} 2 \mathrm{P}$ as a paternalistic attempt at preserving and/or expanding Western hegemony, R2P advocates advanced two arguments. First, they argued that R2P was not, in fact, a solely Western product. In 2009, the year of the publication of the Secretary-General's report outlining the three-pillars approach (United Nations 2011), Ramesh Thakur and Thomas G. Weiss argued that 'sovereignty as responsibility is not really a North-versus-South issue other than at a misleadingly superficial level' (Thakur and Weiss 2009). Two years later, Rama Mani and Weiss published an edited volume entitled 'The Responsibility to Protect: Cultural Perspectives in the Global South', which set out to 'uncover whether this norm and its founding values have resonance and grounding within diverse cultures' (Mani and Weiss 2011, quotation from blurb). Thakur and Weiss, key architects of the ICISS report, were aware that it was important that R2P was not perceived as a solely Western idea if it was meant to appeal internationally. Sampford and Thakur (2015) echoed Mohamed Sahnoun (2009), ICISS co-chair, in arguing that 'in many ways R2P is a distinctly African contribution to global human rights' (48). Amitav Acharya 
(2013, 2015) supported the idea that R2P did not originate solely in the West. 'The real issue about the creation and diffusion of R2P', he argued, 'has to do with the question of agency' $(2013,468)$. Without certainty about the origins of the norm 'there is likely to be controversy ... mistrust and even rejection of what is without doubt one of the most important and attractive of the new international principles' (ibid).

Demonstrating R2P's diverse origins was one approach. Another, second approach was an emphasis on the role of regional organisations. R2P advocates argued that regional organisations should become the main institutional locus of conflict prevention and resolution (Piiparinen 2012). From a theoretical standpoint, the idea that regional organisations can reconcile universalism and particularism goes back to the English School theorist Hedley Bull. Bull argued that the role of regional organisations is to 'occupy the middle ground between states on the one hand, and global organisation on the other' (Bull 2002, 294). From this perspective regional organisations play an essential role in regional governance, arguably providing some counterweight to the power projected by great powers and international institutions. In a post-colonial context, regional institutions serve an explicitly antiimperialist, emancipatory function. From this perspective, therefore, regionalism in R2P could help R2P overcome the imperialist critique. In policy terms, regionalism had a significant impact on the conceptual development of R2P. Whereas the ICISS report had referred to regional organisations as a kind of third-best option if the Security Council was deadlocked and the General Assembly unable to authorise decisive action through the 'Uniting for Peace' procedure, action could be taken 'by regional or sub-regional organizations under Chapter VIII of the Charter, subject to their seeking subsequent authorization from the Security Council' (ICISS 2001, XIII). In the subsequent years, regionalism took a more pronounced role in the conceptual architecture of the principle. In 2005, the World Summit Outcome Document specifically referred to the role of regional organisations (United Nations 2005, para 139). Several years later, regionalism had become ingrained as an essential element of R2P, with the Secretary-General's annual report of 2011 dedicated exclusively to a discussion of the role of regional organisations in the implementation of the R2P (United Nations 2011).

A third approach in addressing the postcolonial critique emerged not from within academia, but from within the policy community: Brazil's 'Responsibility While Protecting', or 'RwP' (A/66/551-S/2011/701). The impetus for the concept paper stemmed from the perceived problems with the ways in which R2P had been implemented in the case of Libya. The concept paper contained a diverse set of proposals, most of which were not original, but simply re-stated ideas that were already inherent in the R2P as outlined in the 2005 outcome document (intervention as contingent on Security Council authorisation; the use of force as a last resort) or that were associated with the concept (an emphasis on prevention). The innovative, original elements of the proposal were its reference to action that was 'limited to the objectives established by the Security Council' (11(f)) and especially its call for procedures to 'monitor and assess the manner in which resolutions are interpreted and implemented to ensure responsibility while protecting' (11(h)) and the Security Council's role in ensuring 'the accountability of those to whom authority is granted to resort to force' (11(i)). Essentially, this amounted to a concrete call for the instatement of mechanisms and procedures to monitor and verify the adherence to mandates, and the assessment of interventions against their stated objectives. The concept paper was not so much a direct effort to promote R2P, than an effort to restrain R2P in those cases in which it was invoked. In doing so, however, the proposal helped move the debate forward. 
Despite these efforts at addressing the postcolonial critique, scepticism remained. In a special issue on the publication of 'Perilous Interventions' (Puri 2016), Hardeep Singh Puri, a retired senior Indian diplomat and India's permanent representative to the United Nations in New York between 2009 and 2013, argued that interventions, even when motivated by humanitarian concerns, were often a pretext for interventions on other grounds, and the destruction caused by these interventions usually defeated the humanitarian purpose. The arguments are in line with India's position on the UN Security Council during Puri's time in office (Hall 2016), suggesting that the postcolonial critique continues to influence perceptions in policy circles (arguably the area in which there has been most progress in terms of forming a 'consensus'), and that neither arguments outlined above (regarding the origins of the norm; and the role of regional organisations) have been successful at putting these concerns to rest. ${ }^{7}$ In response to Puri's arguments, James Pattison (2016) highlighted the potential perilousness of noninterventon, suggesting that 'the counterfactual requires one to ask what would have happened if there had not have been an intervention' (221) - in other words, back to the debate on the question of whether R2P is too little, or too much. Puri's contribution seems to suggest that when in doubt, states with a colonial history are more likely than not to err on the side of caution, taking a non-interventionist line.

Nevertheless, the general shift in the discourse in policy circles does suggest that, on balance, some advances have been made in terms of allaying the postcolonial critics' doubts. The same cannot, however, be said for the critique stemming from the pacifist camp. Here, R2P proponents' efforts at forging a consensus encountered rock solid objection - which is entirely unsurprising given the extreme categorical normative position in which this critique is grounded. R2P proponents' efforts to stress the preventative dimension of R2P was primarily aimed at convincing postcolonial critics, but may also have sought to address the concerns of pragmatic pacifists and some feminists. The Secretary-General's report of 2013 dealt exclusively with the dimension of prevention (United Nations 2013), and R2P advocates continued to de-emphasise the use of force. The primary avenue for doing so was through focusing on 'prevention' as a core component of R2P. The Secretary-General's report of 2013 focused on state responsibility and prevention (United Nations 2013). Much advocacy work subsequently went into promoting the idea that R2P was not just military intervention; not just 'reaction' with 'prevention' and 'rebuilding' tagged on; and not just pillar three with pillars one and two added for special effect. 'Most agree that prevention is the most important aspect of the Responsibility to Protect', Sheri Rosenberg argued (2009). However, de-emphasising coercive intervention did not do away with the use of force as an important element of R2P. Thomas Weiss, who led the research team for the ICISS report together with Stanlake Samkange, and who was (and still is) one of R2P's foremost advocates, argued in 2011 that 'we have witnessed not too much but rather too little armed force to protect human lives over the last decade' and that the emphasis on prevention in the interpretation of R2P is 'politically correct but counterproductive' (Weiss 2011). Given this from one of the central norm proponents, it is perhaps unsurprising that the pacifist critique failed to dissipate and explains why, in 2014, after over a decade of R2P advocacy, another R2P advocate, Cristina Badescu, still thought it necessary to 'clarify why the R2P framework is not solely about the use of military force' (Badescu 2014).

\footnotetext{
${ }^{7}$ However, it is worth noting that by the time he left office, Puri's stance had shifted to one of qualified R2P supporter. 'In my view, if the concept of R2P is to survive ... it must be anchored in the concept of RwP ... Then alone will the international community have enough confidence to support action under R2P.' (Puri 2016, 3140)
} 
On the whole, however, pacifist arguments, given their categorical rejection of the use of force, has since played a marginal role at best in the academic debate. Nevertheless, more recently they have found expression in policy circles. For example, the World Council of Churches, paradoxically (given that Just War principles that were so influential in framing the criteria that were at the heart of the ICISS report originate in Christian philosophy), has taken a critical view on R2P, and many Christian organisations remain sceptical about R2P (Hankins 2013). From the perspective of R2P advocacy, this is disappointing given that the inclusion of the just war criteria in the ICISS report suggests that the theoretical basis for a potential alliance on R2P may have existed. However, in 2011 the World Council of Churches - almost as an overt rejection of R2P - embraced a concept of 'Just Peace' (World Council of Churches 2011). 'Just Peace' stands in stark opposition to the 'Just War' in that it categorically rejects the use of force save for exceptional circumstances - in other words, a default pacifist position. The doctrine regards justifications of armed conflict as 'increasingly implausible and unacceptable' and 'it embraces social justice, the rule of law, respect for human rights and shared human security' (ibid, article 10, 4-5). Just Peace endorsed R2P, but, at the same time, the document stated that 'we feel obliged as Christians to go further - to challenge any theological or other justifications of the use of military power and to consider reliance on the concept of a "just war" and its customary use to be obsolete' (article 23, 8, emphasis in original). The language suggests that R2P was still being perceived as a concept prone to serve as a pretext for the use of force - again, 'too much', rather than 'too little'.

Secular civil society organisations similarly continue to critique R2P on pacifist grounds. A large proportion of non-governmental organisations (NGOs), especially those involved in the provision of humanitarian aid in conflict zones, remain sceptical of R2P. Although 89 NGOs are presently members of the International Coalition for the Responsibility to Protect $(\text { ICRtoP })^{8}$ a large number of NGOs remain sceptical about R2P. Many NGOs originate in broader civil society movements linked to anti-war, peace activist campaigns (Weissman 2010). Consequently, they are pacifist by definition, and the ideological heritage of these origins continues to shape their policies. Relief agencies are wary of aligning themselves with ideologies that they believe may promote military approaches to ending conflict and protecting human rights. 'If the purpose of humanitarian action is to limit the devastation of war', argues Fabrice Weissman, 'it cannot be used as a justification for new wars' (199). This scepticism has been shared by numerous NGOs, including Médecins Sans Frontières and the International Committee of the Red Cross. On the whole, therefore, most NGOs are still, at best, careful supporters of R2P, reflecting the continued sway pacifist arguments hold over the wider policy community.

In contrast, with regards to the feminist critique, R2P norm advocacy may have been a little more successful; and, vice versa, the feminist influence on the conceptual development of $\mathrm{R} 2 \mathrm{P}$ has been substantial. Whereas the instinctive response to $\mathrm{R} 2 \mathrm{P}$ had been one of scepticism due to R2P's association with the use of force, the feminist approach to R2P underwent something of a U-turn when some feminists began arguing that R2P could serve as a vehicle for promoting women's rights (Harris-Rimmer 2014). The strategy of emphasising prevention on one hand, and aligning R2P with the WPS agenda on the other, helped mainstream R2P and defused some of the feminist scepticism. In 2012, in a special issue of Global Responsibility to Protect on R2P and Sexual and Gender Based violence (SGBV), Eli Stamnes argued that the gender perspective needed to be mainstreamed into the implementation of R2P (Stamnes 2012). Stamnes suggested this could be achieved in two ways: first, by identifying and acting upon women's experiences in conflicts that give rise to

\footnotetext{
${ }^{8}$ An umbrella organisation representing NGOs that support R2P
} 
$\mathrm{R} 2 \mathrm{P}$ crimes, and, second, promoting women as active agents in the prevention of R2P crimes. Davies and Stamnes suggested that SGBV is a war crime and a crime against humanity (Davies and Stamnes 2012). The entire special edition was devoted to the question of establishing whether it was helpful, from a policy perspective, if R2P and WPS aligned their prevention and protection agendas (ibid). Davies and Stamnes pointed to the growing literature that identified gender inequality as a significant indicator of the likelihood of conflict. Consequently, the authors supported combining forces between WPS and R2P. In 2014, Susan Harris Rimmer argued that 'more movement around the protection agenda of R2P advocates ... could be interpreted as a sign of engagement with a feminist agenda of women's empowerment and participation ...' (ibid.). Consequently, much work focused on the relationship between R2P and the Women, Peace and Security (WPS) agenda, discussing how the WPS agenda could be mainstreamed into R2P implementation efforts. Some feminists argued that R2P, if it was framed correctly, could promote the WPS agenda (Davies et al 2013). Pro-R2P feminists and WPS agenda supporters subsequently began promoting R2P themselves, helping to defuse the pacifist-feminist argument by emphasising R2P's preventative dimension. Sara Davies argued that there is a 'shared interest between the two agendas on the benefit of preventive diplomacy, first and foremost' (Davies 2014). Consequently, R2P advocacy now incorporates the WPS agenda; and vice versa, the WPS agenda is advocating for R2P. Ultimately, this synergy has benefited both of these agendas (Davies et al 2013).

This is not to say, however, that the feminist critique has dissolved entirely, but the critique now revolves much more around the problem of mainstreaming the gender perspective into R2P implementation efforts, rather than a wholesale rejection of the principle per se. Bond and Sherret, in 2012, argued that 'there remains a significant disconnect between the development of [R2P] and the ever-growing body of work on the gendered nature of peace and security issues' (Bond and Sherret 2012). More recently, Sarah Hewitt has suggested that there remains a 'gender gap' (Hewitt 2016). However, a minority of feminists remain opposed to the principle on theoretical grounds. HarrisRimmer, for example, suggested that Charlesworth's initial critique of R2P remains valid, 'and may have become more entrenched' (Charlesworth 2010; Harris-Rimmer 2015). Harris-Rimmer argued that 'there has undoubtedly been recognition of this critique and more movement around the protection agenda of R2P advocates in the area of the prevention of, and increased accountability for, sexual and gender-based violence', but this could also be 'interpreted as a sign of the paternalist and essentialist gender politics observed in the founding documents of R2P as a concept' (Harris-Rimmer 2015, 267).

Finally, what was the impact of the engagement with pluralist arguments? In a heated debate with Pape in 2013, Evans and Thakur suggested that Pape's evaluation of R2P was focused 'entirely on its original articulation in the ICISS report and totally ignoring its subsequent intellectual and political evolution' (Evans et al 2013). Pape, in response, insisted that although 'the international community has a broad responsibility to protect innocents threatened by their governments', this does not entail 'an obligation or a duty to intervene militarily' (ibid), and that Evans and Thakur exaggerated the 'extent to which the international community has embraced $\mathrm{R} 2 \mathrm{P}$, particularly with regard to armed intervention in humanitarian crises' (ibid). Pape's response illustrates the difficulties in addressing a critique that stems from inherently opposed basic normative assumptions, and indeed, R2P advocates' success at addressing this critique has been little or none - with pluralist critics continuing to harbour serious reservations about a principle they find deeply unsettling. 


\section{Consensus or Continued Controversy? Implications for the implementation of the principle of Responsibility to Protect}

The idea of R2P was never ideologically neutral. The principle sought to advance specific principles and to influence political behaviour in a way that corresponded to a particular worldview. It was conceptualised by cosmopolitans, represented a solidarist worldview, and was advocated for by liberal individuals and institutions. R2P proponents sought to advance a progressive vision of global order that emphasises collective security, multilateralism, and global governance, much like the 'human security' agenda. It was unsurprising, therefore, that the principle was contested by conservative thinkers who regarded $\mathrm{R} 2 \mathrm{P}$ as an attempt to undermine the order of an international society premised on state sovereignty and nonintervention. Postcolonial thinkers viewed the principle with an equal measure of scepticism; as did a range of governments representing states with a post-colonial history or experiences of subjugation to foreign intervention. R2P advocates have had to battle the idea that R2P is a neo-imperialist doctrine; that it imposes unrealistic duties on states or encourages intervention; that it perpetuates, or even promotes, a militarisation of humanitarianism and the normalisation of the use of force in international relations; and that it reinforces a gendered understanding of conflict, depriving women of political agency. R2P proponents have engaged with all of these arguments, although not with an equal measure of success.

Nevertheless, in just over a decade, R2P has had a significant impact on the international discourse on intervention and humanitarianism. The 'responsibility to protect' has indeed replaced 'humanitarian intervention' as the principal framework for considering policies in response to grave human rights violations. Thakur suggests that today, insistence 'on the discredited and discarded discourse [of humanitarian intervention rather than $\mathrm{R} 2 \mathrm{P}$ ] by selfreferencing western scholars amounts to blatant disrespect to them [former colonized countries], ICISS and all the various group of actors who have embraced R2P as an acceptable replacement' (Thakur 2016b, 418). The changed discourse is also evident in the kind of vocabulary employed by R2P supporters - the shift in tone is particularly evident if we contrast arguments made in relation to Kosovo and Libya or, more recently, Syria. Whereas the previous discourse was focused on whether to intervene, or not - an inflexible binary - the current discourse has moved atrocity prevention, rather than military intervention, into the foreground, enabling the consideration of a range of measures, including limited intervention and non-coercive measures. Michael Ignatieff, one of the ICISS commissioners, for example, suggested in 2000, in relation to Kosovo, that there was a 'right to intervene militarily', and that Kosovo 'met the criteria' for a 'justified intervention' (Ignatieff 1999) - jargon that was more in line with a 'humanitarian intervention' approach to addressing large-scale, systematic human rights abuses. By 2013, in response to the crisis in Syria - no less serious in terms of the magnitude of human suffering, and with similar geopolitical implications - Ignatieff suggested that 'leaving Assad in place ... may be the only way we can protect civilians from carnage ... the protection of civilians in Syria depends on the resumption ... of cease-fire negotiations in Geneva' (Ignatieff 2013).

The new discourse has meant that R2P's critics have had to engage with the ideas introduced, and ultimately have begun couching their own critique in language that uses terminology that reflects agreement with the concept's basic assumptions; above all the idea that a legitimate sovereign state ought to be a responsible state, the 'sovereignty as responsibility' formula at the heart of R2P. In recent years, some of R2P's harshest critics - Mamdani, Chandler, Chomsky, Hehir, O'Connell, or Cunliffe - have been less vocal, and have changed the focus of their critique. Mamdani, Chandler and O'Connell are no longer actively critiquing R2P. Chandler proclaimed 'R2P is dead' in 2015 (2015), with regard to the use of force in the Arab 
Spring, but no longer questioned the R2P as a matter of principle. Similarly, Hehir's critique has shifted in tone: whereas the earlier work constituted a substantive critique of the principle, ${ }^{9}$ his more recent work has revolved exclusively around the extent to which the constructivist accounts of a changing international discourse and norm consolidation have resulted in changing state behaviour (the constructivist/rationalist debate). ${ }^{10}$ The softening of tone and language may suggest that R2P has become established within the academic discourse, and may be responsible for defining expectations about appropriate responses to atrocities, and shaping arguments around intervention and human rights protection - although it may be too soon to tell whether the examples outlined above are indicative of such a trend. Critical voices remain, for example Cunliffe, who still opposes R2P on the basis that it puts in place 'an authoritarian vision of state power, with security elevated over self-determination and representation' (Cunliffe 2016). However, he has also acknowledged that there is a 'consensus on the RtoP' which 'takes for granted the need for systematic exceptions to the norm of non-intervention' (ibid). A tentative argument could therefore be made that R2P advocates have been successful at defusing some of the critique.

$\mathrm{R} 2 \mathrm{P}$ advocacy has been most successful in transforming the concept from one that was primarily associated with the use of force to one that focused on the objective - the prevention of atrocity crimes - rather than the means of achieving this objective. By emphasising the preventative dimension of $\mathrm{R} 2 \mathrm{P}$ and other non-coercive and non-military measures at governments' disposal, the use of force has gradually receded into the background, and is no longer as central as it was in the ICISS report. In hindsight, it appears almost pre-determined that $\mathrm{R} 2 \mathrm{P}$ proponents would have chosen to emphasise the preventative dimension of R2P, given the ability of 'prevention' to defuse much of the critique ('prevention' addressed a range of concerns, providing reassurance that $\mathrm{R} 2 \mathrm{P}$ was not 'too much'). Arguably, the result has been that critics' arguments have had to change their focus, switching their attention away from normative and substantive questions - on which consensus has grown - towards questioning the extent to which this translates into changes in international behaviour. The result has been an array of work focusing on the extent to which $\mathrm{R} 2 \mathrm{P}$ has consolidated as an international norm, as well as the consequences of this normative consolidation on international practice - but the progress in terms of policy advocacy geared towards garnering international support for the principle, focused especially on traditionally sceptical governments, has been more limited.

\section{Conclusions}

Continued R2P advocacy has indeed diminished some of the fears expressed during the earlier part of the 2000s. References to R2P as an imperialist doctrine are now much less common, and the main principles underpinning the concept are beginning to enjoy mainstream support. North African and Sub-Saharan states no longer question the value of

\footnotetext{
${ }^{9}$ Not explicitly, but the choice of vocabulary suggested as much. In 2005, Hehir argued that 'human rights discourse has been commandeered to perpetuate hegemony. The 'consensus' regarding the failings of sovereignty is inherently false and based on Western notions of a hierarchical international order' (Hehir 2005). See also Hehir (2008).

${ }^{10}$ With the notable exception of Hehir, A. 'From Human Security to the Responsibility to Protect: the Co-Option of Dissent'. Michigan State International Law Review., all of his more recent work has focused on one or another aspect of this debate. See, for example, Hehir (2016); Hehir (2015); or Hehir (2015b)
} 
R2P in United Nations debates, routinely expressing support for the principle, although reference is sometimes made to the potential misuse in terms of the principle's application. Perhaps indicative of a recent trend towards international acceptance of the principle at an international level, the General Assembly decided, for the first time since 2005, to include the 'responsibility to protect' in its agenda for its $72^{\text {nd }}$ session in September $2017 .{ }^{11}$

Much of the critique of R2P today revolves around a lack of capacity and robust implementation of the principle (R2P as 'too little'). This is not to say that the traditional objections have dissipated; rather, that they are being drowned out by critical voices pointing out that actual state practice has not been able to hold up with advances in the discourse, with the international responses to the humanitarian crisis in Syria as an all too poignant reminder. Nevertheless, traditional objections rooted in a fear of progression away from settled norms protecting state sovereignty and a default position of an absolute prohibition on the use of force remain strong, within the scholarly and wider epistemic community, and beyond. More work is still needed to consolidate an emerging consensus in policy circles, and then to translate this consensus into the effective implementation of R2P, both in terms of prevention as well as in terms of responses to conflicts that give rise to mass atrocities.

So, has there been a 'continuing growth in acceptance of R2P', as its proponents will have us believe (Evans 2017, 2)? For the time being, R2P remains controversial, despite the advocates' rhetoric of 'consensus'. While something approximating consensus may have been reached in the policy community, at least judging from the pervasiveness of the use of R2P language, a genuine 'consensus' remains much more elusive beyond this sphere, especially in the world of academe, but also amongst civil society organisations and states with a colonial history. Indeed, references to a putative 'consensus' may serve to obfuscate continued scepticism about a progressive norm that challenges a host of traditional assumptions about the normative pillars underpinning international society. In the light of this, R2P norm advocates ought to avoid claiming a consensus exists where it does not, but, on the contrary, encourage open debate and genuine engagement with the critical arguments. What is needed is more, not less, argumentation and debate. R2P proponents would be welladvised to embrace the controversy - and to continue to engage with the critique.

\section{References}

Acharya, Amitav (2013) 'The R2P and Norm Diffusion: Towards a Framework of Norm Circulation', Global Responsibility to Protect 5:4, 466-479

Acharya, Amitav (2015) 'The Responsibility to Protect and a Theory of Norm Circulation, Theorising the Responsibility to Protect. Ramesh Thakur and William Maley (Cambridge: Cambridge University Press)

Adler, Emanuel (1997) 'Seizing the Middle Ground: Constructivism in World Politics', European Journal of International Relations 3:3, 319-363

${ }^{11}$ With a vote of 113 in favour, 21 against, and 17 abstentions (Global Geopolitics 2017). 
Allen, Tim, and Styan, David (2000), 'A Right to Interfere? Bernard Kouchner and the New Humanitarianism', Journal of International Development 12:6, 825-842

Annan, Kofi (1999) 'Two Concepts of Sovereignty', The Economist 18

Annan, Kofi and Mousavizadeh, Nader (2012) Interventions: A Life in War and Peace (London: Allen Lane)

Badescu, Cristina (2014) 'The Evolution of International Responsibility: From Responsibility to Protect to Responsibility While Protecting', International Studies Journal 11:1, 45-77

Badescu, Cristina and Weiss, Thomas G (2010) 'Mispresenting R2P and Advancing Norms: An Alternative Spiral?' International Studies Perspectives 11:4, 354-374

Bellamy, Alex .J. (2005) 'Responsibility to Protect or Trojan Horse? The Crisis in Darfur and Humanitarian Intervention after Iraq.' Ethics \& International Affairs 19:2, 31-54

Bellamy, Alex.J. (2009) Responsibility to Protect: The Global Effort to End Mass Atrocities. (Cambridge: Polity Press).

Bond, Jennifer and Sherret, Laurel (2006) 'A Sight for Sore Eyes: Bringing Gender Vision to the Responsibility to Protect Framework.' INSTRAW.

Bond, Jennifer, and Sherret, Laurel. (2012). 'Mapping Gender and the Responsibility to Protect: Seeking Intersections, Finding Parallels' Global Responsibility to Protect 4:2 133-153.

Bose, Srinjoy and Thakur, Ramesh (2016). 'The UN Secretary-General and the Forgotten Third R2P Responsibility' Global Responsibility to Protect 8:4, 343-365

Boutros-Ghali, Boutros (1992). Report of the UN Secretary-General. 'Agenda for Peace'. United Nations.

Brown, Chris (2013) 'The Antipolitical Theory of Responsibility to Protect'. Global Responsibility to Protect $5: 4,423-442$

Bull, Hedley. (1966). 'The Grotian Conception of International Society', in Hebert Butterfield and Martin Wight (eds.) Diplomatic Investigations: Essays in the Theory of International Politics (Cambridge: Harvard University Press), 51-73

Bull, Hedley (2002) The Anarchical Society: A Study of Order in World Politics. Palgrave, 294-299

Chandler, David (2006) From Kosovo to Kabul and Beyond: Human Rights and International Intervention. Pluto Press

Chandler, David (2010) 'R2P or Not R2P? More Statebuilding, Less Responsibility’ Global Responsibility to Protect 2:1, 161-166

Chandler, David (2015) 'The R2P Is Dead, Long Live the R2P: The Successful Separation of Military Intervention from the Responsibility to Protect'. International Peacekeeping 22:1, 1-5

Charlesworth, Hilary (2010) 'Feminist Reflections on the Responsibility to Protect' Global Responsibility to Protect 2:3, 232-249

Childress, James.F (2010). 'Pacifism in Mark Bevir (ed) Encyclopaedia of Political Theory (Thousand Oaks, CA: SAGE), 1004-1008.

Cockburn, Cynthia (2007) From Where We Stand. Zed Books.

Cockburn, Cynthia (2012) Antimilitarism: Political and Gender Dynamics of Peace Movements. Palgrave Macmillan. 
Cunliffe, Phillip (2010) 'Dangerous Duties: Power, Paternalism and the "Responsibility to Protect" Review of International Studies 36 (special issue)

Cunliffe, Philipp (ed., 2011) Critical Perspectives on the Responsibility to Protect: Interrogating Theory and Practice (Abingdon/Oxon and New York, NY: Routledge)

Cunliffe, Philipp (2016). 'The Doctrine of the "Responsibility to Protect as a Practice of Political Exceptionalism' European Journal of International Relations 23:2, 466-486

Davies, Sara E. and Stamnes, Eli (2012). 'The Responsibility to Protect and Sexual and Gender Based violence (SGBV)'. Global Responsibility to Protect 4:2, 127 - 132

Davies, Sara E., Zim Nwokora, Eli Stamnes and Sarah Teitt (eds,2013). Responsibility to Protect and Women, Peace and Security: Aligning the Protection Agendas. Brill.

Davies, Sara.E(2014) 'R2P and Gender: The Marginalization of Responsibilities'. www.e-ir.info

Deng, F.M. (1995) 'Reconciling Sovereignty with Responsibility: A Basis for International Humanitarian Action.', Africa in World Politics: Post-Cold War Challenges(Boulder, Colo.: Westview), 295-310

Dunne, Tim and Staunton, Eglantine (2016) 'The Genocide Convention and Cold War Humanitarian Intervention' in Alex Bellamy and Tim Dunne (eds)Oxford Handbook of the Responsibility to Protect (Oxford: Oxford University Press), 38-57

Evans, Gareth (2011)'End of the Argument: How We Won the Debate Over Stopping Genocide'. Foreign Policy, December

Evans, Gareth (2017) 'Taking Stock of the Responsibility to Protect: Achievements and Challenges', public lecture, Simon Fraser University, Vancouver, 22 March 2017. Available at http://www.thesimonsfoundation.ca/sites/default/files/Taking\%20Stock\%20of\%20the\%20Responsibility\%20to $\% 20$ Protect-

Achievements $\% 20$ and $\% 20$ Challenges $\% 2 \mathrm{C} \% 20$ public $\% 20$ lecture $\% 20 \mathrm{by} \% 20 \mathrm{G}$. Evans $\% 2 \mathrm{C} \% 20 \mathrm{March} \% 2022 \% 2$ 02017_1.pdf. Last accessed 13/03/2018

Evans, Gareth., Pape, Robert A, and Thakur, Ramesh (2013) 'Correspondence: Humanitarian Intervention and the Responsibility to Protect' International Security 37:4, 199-214.

Finnemore, Martha and Sikkink, Kathryn (1998) 'International Norm Dynamics and Political Change' International Organization 52:4, 887-917

Frazer, Elizabeth. and Hutchings, Kim (2014) 'Revisiting Ruddick: Feminism, Pacifism and Non-Violence' Journal of International Political Theory 10:1, 109-124

Gough, Claire, and Shackley, Simon (2001) 'The Respectable Politics of Climate Change: The Epistemic Communities and NGOs', International Affairs 77:2, 329-346

Hall, Ian (2016), 'Perilous Interventions and the Responsibility to Protect', Special Forum on Hardeep Singh Puri's Perilous Interventions: The Security Council and the Politics of Chaos. Global Responsibility to Protect 9, 203-210

Haacke, Jürgen (2009) 'Myanmar, the Responsibility to Protect, and the Need for Practical Assistance', Global Responsibility to Protect 1:2, 156-184

Haas, Peter .M (1992) 'Banning chlorofluorocarbons: epistemic community efforts to protect stratospheric ozone', International Organization 46:1, 187-224

Hankins, Rick (2013) 'Confronting Genocide: Christianity and the Responsibility to Protect' Doctorate. Claremont Graduate University. See esp. 77-98 
Harris Rimmer, Susan (2014) 'When WPS Met CEDAW (and Broke Up with R2P?). http://www.e-ir.info, last accessed 17/06/2018

Harris-Rimmer, Susan (2015) 'Is the Responsibility to Protect Doctrine Gender-Neutral?', Thakur, Ramesh, and Maley, William,Theorising the Responsibility to Protect (Cambridge: Cambridge University Press), 266-284

Hehir, Aidan (2005) 'Structural Imperatives and the "Globalisation" of Human Rights', available at https://www.bradford.ac.uk/social-sciences/peace-conflict-and-development/issue-6/Globalisation-of-HR-finalversion-edited.pdf, last accessed 17/06/2018

Hehir, Aidan (2008) 'The Normative Flaws', in Humanitarian Intervention after Kosovo (Palgrave Macmillan), 76-96

Hehir, Aidan (2014) 'From Human Security to the Responsibility to Protect: the Co-Option of Dissent'. Michigan State International Law Review 23:3, 675-700

Hehir, Aidan (2015) 'The Dog That Didn't Bark? A Response to Dunne and Gelber's Analysis of RtoP's Influence on the Intervention in Libya', Global Responsibility to Protect 7:2, 211-224

Hehir, Aidan (2015b) ‘Bahrain: An R2P blind spot?', The International Journal of Human Rights 19:8, 11291147

Hehir, Aidan (2016) 'Assessing the influence of the Responsibility to Protect on the UN Security Council during the Arab Spring', Cooperation and Conflict 51:2, 166-183

Hewitt, Sarah (2016) 'Overcoming the Gender Gap: The Possibilities of Alignment between the Responsibility to Protect and the Women, Peace and Security Agenda', Global Responsibility to Protect 8:1, 3-28

Hopf, Ted (1998), 'The Promise of Constructivism in International Relations Theory', International Security 23:1, 171-200

Ignatieff, Michael (1999) 'Is Military Intervention Over Kosovo Justified?’ Prospect, June 1999

Ignatieff, Michael (2013), 'Libya, Syria, and R2P', Policy Options 34:8

International Commission on Intervention and State Sovereignty (2001) The Responsibility to Protect: Report of the International Commission on Intervention and State Sovereignty. Ottawa.

Keck, Margaret E. and Sikkink, Kathryn (1998): Activists Beyond Borders: Advocacy Networks in International Politics (Cornell University Press)

Keck, Margaret E. and Sikkink, Kathryn (1999) 'Transnational Advocacy Networks in International and Regional Politics', International Social Science Journal 159, 89-101

Knight, W Andy (2011) 'The Development of the Responsibility to Protect: From Evolving Norm to Practice.' Global Responsibility to Protect 3:1, 3-36

Kuperman, Alan (2008) 'The Moral Hazard of Humanitarian Intervention: Lessons from the Balkans', International Studies Quarterly 52:1, 49-80

Mamdani, Mahmood (2010) 'Responsibility to Protect or Right to Punish?', Journal of Intervention and Statebuilding 4:1, 53-67

Mani, Rama and Weiss, Thomas G (eds 2011) Responsibility to Protect: Cultural Perspectives in the Global South (Routledge, quotation from blurb)

Meyer, Morgan (2015) 'Epistemic Communities and Collaborative Research', in International Encyclopedia of the Social \& Behavioral Sciences, 2nd edition, volume 7, 862-866 
Mamudu, Hadii M. (2011) 'The Nature, Scope, and Development of the Global Tobacco Control Epistemic Community', American Journal of Public Health 101:11, 2044-2054

Nastranis, J (2017) 'R2P Back on the UN General Assembly's Agenda After 12 Years' Global Geopolitics, 18 September 2017. Available at http://globalgeopolitics.net/2017/09/18/r2p-back-on-the-un-general-assemblysagenda-after-12-years/. Last accessed 17/06/2018

O’Connell, MaryEllen and Thakur, Ramesh (2008) 'The R2P Controversy'. Available at https://www.globalpolicy.org/component/content/article/154/26068.html, last accessed 17/06/2018

O’Connell, Mary Ellen (2009) 'Sri Lanka Needs Peace, Not R2P.' Available at http://www.eir.info/2009/04/28/sri-lanka-needs-peace-not-r2p/, last accessed 17/06/2018

O’Connell, Mary Ellen (2010) 'Responsibility to Peace: A Critique of R2P.', Journal of Intervention and Statebuilding 4:1, 39-52

Pape, Robert A (2011), 'The New Standard for Humanitarian Intervention'. The Atlantic, April 4 ${ }^{\text {th }}, 2011$.

Pape, Robert A. (2012) 'When Duty Calls: A Pragmatic Standard of Humanitarian Intervention', International Security 37:1

Paris, Roland (2014) 'The 'Responsibility to Protect' and the Structural Problems of Preventive Humanitarian Intervention', International Peacekeeping 21:5, 569-603

Pattison, James (2017) 'Perilous Noninterventions? The Counterfactual Assessment of Libya and the Need to Be a Responsible Power', Global Responsibility to Protect 9:2, 219-228

Piiparinen, Touko (2012) 'Norm Compliance by Proximity: Explaining the Surge of Regional Actors in Responsibility to Protect', Conflict, Security and Development 12:4, 387-415

Puri, Hardeep Singh (2016) Perilous Interventions: The Security Council and the Politics of Chaos (Harper Collins)

Risse, Thomas (2000) “'Let's Argue!': Communicative Action in World Politics', International Organization $54: 1,1-39$

Rosenberg, Sheri P (2009) 'Responsibility to Protect: A Framework for Prevention', Global Responsibility to Protect 1:4, 442-477

Sahnoun, Mohamed (2009) 'Africa: Uphold Continent's Contribution to Human Rights, Urges Top Diplomat', allAfrica.com, $21^{\text {st }}$ July 2009. Available at http://allafrica.com/stories/200907210549.html, last accessed $13 / 03 / 2018$

Sampford, Charles and Thakur, Ramesh (2015) 'From the Right to Persecute to the Responsibility to Protect: Feuerbachian inversions of rights and responsibilities in state-citizen relations', in Thakur, Ramesh, and Maley, William (eds) Theorising the Responsibility to Protect (Cambridge: Cambridge University Press), 38-58

Serrano, Monica (2011) 'The Responsibility to Protect - True Consensus, False Controversy', Development Dialogue, March 2011

Serrano, Monica (2011) 'The Responsibility to Protect and its Critics: Explaining the Consensus', Global Responsibility to Protect 3:4, 425-437

Stamnes, Eli (2012) 'Integrating Gender Perspectives into Policies and Practices', Global Responsibility to Protect 4:2, 172-197

Teichman, Jenny (1982) 'Pacifism', Philosophical Investigations 5:1

Thakur, Ramesh and Weiss, Thomas G(2009) 'R2P: From Idea to Norm - and Action?' Global Responsibility to Protect 1:1, 22-53 
Thakur, Ramesh (2015) 'R2P's 'Structural' Problems: A Response to Roland Paris', International Peacekeeping $22: 1,11-25$

Thakur, Ramesh (2016a) 'Rwanda, Kosovo, and the International Commission on Intervention and State Sovereignty', Bellamy, Alex and Dunne, Tim (eds), Oxford Handbook of the Responsibility to Protect (Oxford: Oxford University Press), 94-113

Thakur, Ramesh (2016b) 'The Responsibility to Protect at 15', International Affairs 92:2, 415-434

Thakur, Ramesh (2017) 'From Humanitarian Intervention to R2P: Cosmetic or Consequential?', in Thakur, Ramesh, The United Nations, Peace and Security: From Collective Security to the Responsibility to Protect, $2^{\text {nd }}$ edition (Cambridge: Cambridge University Press), 272-300

United Nations (2005) World Summit Outcome. General Assembly A/60/L.1

United Nations (2009) 'Implementing the Responsibility to Protect: Report of the Secretary-General', United Nations A/63/677

United Nations (2011) 'Letter dated 9 November 2011 from the Permanent Representative of Brazil to the United Nations addressed to the Secretary-General', A/66/551-S/2011/701

United Nations (2011) 'The Role of Regional and Subregional Arrangements in Implementing the Responsibility to Protect: Report of the Secretary-General', A/65/877-S/2011/393

United Nations (2013) 'Responsibility to Protect: State Responsibility and Prevention'.

Verdun, A. (1999) 'The role of the Delors Committee in the creation of EMU: an epistemic community?' Journal of European Public Policy 6:2, 308-328

Weiss, T.G. 2004. 'The Sunset of Humanitarian Intervention? The Responsibility to Protect in a Unipolar Era'. Security Dialogue 35(2), pp. 135-153.

Weiss, Thomas G (2006) 'R2P After 9/11 and the World Summit'. Wisconsin International Law Journal 24:3

Weiss, Thomas G (2011). 'RtoP Alive and Well After Libya', Ethics \& International Affairs 25:3

Weissman, Fabrice (2010) "'Not in Our Name": Why Médecins Sans Frontières Does Not Support the "Responsibility to Protect", Criminal Justice Ethics 29:2, 194-207

Welsh, Jennifer (2013) 'Norm Contestation and the Responsibility to Protect', Global Responsibility to Protect 5:4, 365-396

World Council of Churches (2011) 'An Ecumenical Call to Just Peace', Geneva

Youde, Jeremy (2005) 'The Development of a Counter-Epistemic Community: AIDS, South Africa, and International Regimes'. International Relations 19:4, 421-439 